\title{
Paradigmatics, semantics and pragmatics of the imperative in German
}

\author{
Elena Bodnaruk $^{1, *}$ and Larisa Reznichenko ${ }^{1}$ \\ ${ }^{1}$ Northern Arctic Federal University, 163002, Naberezhnaya Severnoj Dviny, 17, Arkhangelsk, Russia
}

\begin{abstract}
The article studies the imperative, one of the most significant linguistic means of expression of incentive in the German language. Traditionally the imperative belongs to forms of a verbal mood and is a morphological unit. Forming a special type of the sentence, an incentive sentence, the imperative can also be recognized as a syntax unit. The paradigm of the imperative in a narrow sense consists of the forms of the $2^{\text {nd }}$ person singular and plural. In a broad sense it also includes polite forms (with Sie pronoun) and forms of joint action (with wir pronoun). From the semantic point of view, the imperative has such features as deictivity, controllability of action, beneficiation, subordination, aim-orientation and futurity. The imperative is involved in the considerable repertoire of speech acts. In the studied corpus of examples extracted from direct speech of characters of fictional discourse it is frequent in such speech acts of incentive character as request, advice, demand, order, permission, offer, invitation and some other. Besides, it is widespread in the contactive and metacommunicative speech acts which are characterized by the blurred imperativeness. In rare cases the imperative can be involved in the non-incentive speech acts of the modal-evaluative and informing character.
\end{abstract}

\section{Introduction}

The anthropocentrism of the modern linguistic paradigm focuses attention of researchers on studying the person as a subject of thought and speech and, therefore, places communicative behavior of the person into the center of consideration. Among the most important features of communicative behavior of the person is the expression of incentive to action. The incentive to the action can be expressed by various means. One of the main means of its expression is the imperative.

The imperative plays a vital role in the organization of interpersonal communication in a natural language. The functional importance of the imperative is illustrated by the fact that forms of the imperative can be referred to the language phenomena of universal character as they are presented in the majority of languages of the world $[1,2]$.

It can be argued that the genesis of language itself began with the use of imperative statements $[3,4]$.

The present article considers the main characteristics of the imperative in the German language, in particular, the structure of the paradigm, as well as specifics of the semantic and pragmatic functions of the imperative in the direct speech of the German fictional discourse.

\section{Grammatical status of the imperative}

A large number of works are devoted to studying the imperative. In spite of the fact, its grammatical status still remains a subject of numerous discussions.
According to the traditional point of view, the imperative is a verbal mood along with the indicative and conjunctive. The mood is understood as a grammatical way of expressing the attitude of the utterance towards reality from the point of view of the speaker [5].

The speaker usually estimates the contents of the utterance as corresponding to reality or as unreal [6].

Probably, in this regard, in the second half of the 20th century linguistic studies began to appear in which the imperative was excluded from the system of moods [e.g., 7, 8, 9]. The matter is that unlike the indicative and conjunctive the imperative does not deal with "evaluation of reality of an utterance".

The imperative is tied to imperative communicative type of the sentence, thus joining the opposition "narration-question-requirement" rather than expressing real or unreal situation. Unlike forms of the indicative and conjunctive the imperative cannot form the complete predication assuming the existence of both a predicate, and a subject in the sentence.

In a number of works the imperative is treated as "half-mood", and the form of the imperative is considered as "semi-finite" [10 11, 12]. This position is explained by the fact that the imperative in German demonstrates features of both personal and impersonal forms. It does not change persons (as only the form of the $2^{\text {nd }}$ person is recognized as imperative in a narrow sense), but it has several forms: Sprich! vs. Sprecht! The imperative is similar to impersonal forms in the fact that it is not usually connected with a personal subject in the sentence.

\footnotetext{
* Corresponding author: bodnaruk@rambler.ru
} 
Thus, on the one hand, forms of the imperative can be recognized as verbal forms, on the other hand, the existence of the properties other than forms of the indicative and a conjunctive are obvious.

Since the imperative in German forms one of communicative types of the sentence, it can also be qualified as a syntax unit, making along with narrative and interrogative sentences (in which forms of an indicative and a conjunctive are used) a special syntactic category [e.g., 9]. Probably, in this regard, W. Abraham considers the imperative as "a sentence mood" (Satzmodus) while the indicative and conjunctive are considered as "a verb mood" (Verbmodus) [13].

The above-mentioned facts indicate that the imperative represents a special grammatical phenomenon related both to the field of morphology and to the field of syntax.

The typical (prototypical, canonical) forms of the imperative not only in the German language, but also in many other languages of the world are forms of the $2^{\text {nd }}$ person singular and plural [14], they form an imperative paradigm properly.

These forms in German are functionally adjoined by the imperative forms of politeness, representing the syntactic structures including a verbal form and a polite form of a personal pronoun in postpositions (Machen Sie die Tür auf!) and also by forms of "joint action", i.e. forms of the $1^{\text {st }}$ person plural with wir pronoun (Machen wir das!).

These forms are sometimes included by linguists into the imperative paradigm, making it very inhomogeneous from the structural point of view. The example of an expanded paradigm is the imperative paradigm of $\mathrm{F}$. Simmler which includes: 1) imperative of the singular (Geh!); 2) imperative of the plural (Geht!); 3) imperative of a polite distance (Gehen Sie!); 4) imperative of a reduced distance (Gehen wir ins Bett und werden schnell gesund! - the doctor addresses the patient) [15]. Beyond the scope of a paradigm F. Simmler leaves, however, the forms of an exhortative (Gehen wir ins Kino!) in which the speaker is included into the list of performers of the action. At the same time, these forms can also join the imperative paradigm due to the presence of incentive semantics [see, e.g.: 16].

Thus, the question of the structure of an imperative paradigm in German should be considered open. The paradigm in a narrow or general sense includes only forms of the $2^{\text {nd }}$ persons singular and plural. The paradigm in the broadest sense can include at least two more syntactic structures having imperative meaning. Such approach, on the one hand, compensates the correlation with the first person (the invitation to a joint action), which is absent in the imperative in traditional understanding, on the other hand, the polite form of the address to the second person necessary for situations of official communication is introduced into a paradigm.

\section{Semantics of the imperative}

Following Yu.P. Knyazev we will consider the speech causation of reality change to be the most specific component of the meaning of the imperative [17]. "The Speaker, by the fact of the utterance, tries to cause fulfilment of some action (explicitly indicated in this utterance)" [4].

The imperative forms cannot be considered real or unreal as they do not express any fact which can be characterized as real or unreal [e.g., 1]. However, the attempts to refer the imperative to a realis (in the broadest sense) [18], or, on the contrary, to irrealis [2, 19] are made in linguistic literature. The imperative can also be associated with the meaning of potentiality, connecting irreality with reality, i.e. converting some unreal situation into real [20].

The sphere the imperative' use is usually limited only to situations of immediate communication, which evidently indicates a deictic character of imperative forms [about deixis see: 21 ].

A number of restrictions are connected with orientation of the imperative in a speech situation and its deictivity:

1. the use in the form of the $2^{\text {nd }}$ person without a subject, in view of redundancy of the latter,

2. non-use in the indirect speech,

3. impossibility of being used in a subordinate clause.

The utterance with the imperative presupposes the existence of the addressee of will (the listener) in a communicative situation along with the addresser (the speaker), but the response is not required from the former. The reaction of the listener can be limited to the fulfillment of the action.

Expressing his will, the speaker also acts as the controller of the situation; he believes that the listener can perform the action being discussed. In this regard in many languages of the world we can find restrictions in formation of imperative forms from the verbs designating uncontrollable actions [22].

Imperative utterances are characterized by beneficiation, because as a result of the fulfillment of the action a new situation arises that can be treated in advantage of a) the speaker, b) the addressee, c) both, d) all participants and witnesses of the imperative act [23].

The use of the imperative is also connected with the concept of subordination, as the speaker, expressing his will, puts himself above or, on the contrary, lower in status than the listener.

And, finally, the use of the imperative correlates with the concept of the aim which is pursued by the speaker while committing the imperative speech act. The purpose is execution of any action to which the speaker induces the other person, or, on the contrary, prevention of the undesirable action.

All features of semantics listed above as well as the cases of usage of the imperative connect it directly with the area of the future, as the situation discussed in the imperative sentence has to take place after the moment of speech.

The German imperative has no grammatical category of time. The lack of special grammatical category of 
time is connected with the fact that imperative function eliminates the "freedom of alternation of tenses" which is caused by the indicative [23] and also by the conjunctive - to some extent.

Nevertheless, some researchers pay attention to temporal variability in the use of the imperative, for example, present-futurity perspective of imperative situations $[23,24]$.

The present as temporary characteristic of the imperative is accepted because the imperative is focused on a communicative situation in the present, where the will expression is formulated. Yet, the action discussed in the utterance belongs either to the future proper, to the future resulting from the present, or to the future as one of the time spans forming the meaning of timelessness.

The action named as an imperative form is not given as objective reality at the moment of expressing the will. Otherwise the need to appeal to the interlocutor with order, request, advice etc. becomes irrelevant. For example, it is senseless to address the standing person with such will expression as Get up! Therefore, when determining temporal localization of the imperative action, it is logical to recognize that it is not objective reality at the time of will expression, and the addressee can execute the speaker's will after some period of time. The duration may vary from few seconds to several years [25].

Difficulties arise with the definition of a major meaning of the imperative. It is often understood as the order [e.g.: 26]. We can additionally distinguish particular semantic interpretations of utterances with the imperative meaning being the result of the interaction of this meaning with the situations arising when imperatives are uttered.

S. Heinold notes the meaning of order / requirement (Steh auf!), request (Geh bitte heim!), ban (Fass das nicht an!), wish (Werde schnell gesund!), advice (Nimm lieber die frische Hefe, um den Kuchen zu machen!) [26]. In "Grammatik der deutschen Sprache" we can also find information about the use of the imperative for expression of concession (Besitze ruhig ein großes Vermögen. Es wird dir sicherlich nichts nützen) and condition (Besitze Geld und du hast Einfluss) [11]. There is an opportunity of interjectional use of the imperative (Geh! Komm! Warte! Halt!), and of narrative use (Aber Moritz aus der Tasche zieht die Flintenpulverflasche und geschwinde - stopf, stopf, stopf - Pulver in den Pfeifekopf) [26].

The range of meanings within the frame of imperative semantics is so wide that it is difficult to be fully described. The solution to this problem was offered by V.S. Hrakovsky. He supposed that in each concrete language the number of semantic interpretations of imperative sentences equals to the number of nonsynonymous verbs of speech causation, which are presented in this language (to order, to resolve, etc.) [27].

The complexity in the semantic analysis of the imperative is also connected with the large number of synonyms practically in all languages, including German. It is possible to explain the competing forms of expression of imperative semantics drawing on various bases. Social status of participants of the speech act and specifics of communicative situation play an important role. As well as the aspiration to gradation of degree of directive force of the utterance. It is known that expression of the order or requirement in a categorical form can be face-threatening for the addressee and can cause various undesirable consequences. Therefore the addresser is forced to construct the utterance in the most effective way so that it is not followed by the "loss of the face" by the addressee. Only then the principle of "social interaction" is completely observed.

The back side of this principle is the variety of means of expression of incentive semantics. The most frequent imperative synonyms in German are: a) constructions with modal verbs (Du sollst mir helfen!), b) infinitive forms (Einsteigen!), c) Präsens and Futur I (Du gehst schlafen!), d) Konditionalis I (Würdest du mir bitte helfen?), e) forms of participle perfect (Stillgestanden!). The synonymy is observed also at the syntactic level: verbless offers (Vorwärts! Halbes Pfund Brot!), subordinate clauses with conjunction dass (Dass du mir sofort schlafen gehst!) and some other constructions.

It is noted that the European languages developed a considerable repertoire of the means capable of expressing the imperative meaning [22]. In a sense the structure of these means reflects the social structure of society as imperatives are embedded into cultural practices and reflect societal structures [22].

\section{Speech acts with the imperative}

Semantics of the imperative is specified in speech acts in which it is used. For the analysis of speech acts with participation of the imperative we have chosen three works of modern fiction writers: Ch. Hein "Landnahme" (2005), D. Kehlmann "Ruhm" (2009) and I. Noll "Ehrenwort" (2010) with a number of pages totaling to 922, written in German. In these works direct speech of characters was extracted, then, using the method of continuous selection, more than 300 examples with imperatives were chosen.

According to empirical data, the imperative, to which we refer forms of the $2^{\text {nd }}$ person singular and plural, forms with a pronoun of the $1^{\text {st }}$ person plural wir and polite forms with Sie, has occurred in the following speech acts: requests (108 cases of the use), advice (49), demand (27), consolation (13), order (12), permission (10), offer (10), entreaty (8), invitation (8), persuasion (6), wish (6), threat (6), instruction (5), command (4), warning (2), consent (2), appeal (2) encouragement (1), refusal (1), assignment (1).

It is obvious that the imperative is typical first of all for speech acts of imperative character in which the speaker demonstrates his will with the purpose to produce an impact on the listener (the addressee of the will) and to induce him to perform certain actions, or to refuse to carry out this act.

The addressee can be obliged to execute the will of the speaker (command, order, demand, assignment). The necessity of fulfillment of the action is usually connected 
with the fact that the addressee for some reason depends on the speaker. E.g.:

\section{Order:}

The mother to the son: «Stell die Heizung auf Sparflamme, Ende Februar friert es nicht mehr über Nacht!, befahl sie.» (Noll, 25)

Adults to children: «Da werden sie nicht viele von uns finden, Junge. Gut, dass du es uns gesagt hast, nun verschwindet. Das ist hier nichts für Kinder. Haut ab. .» (Hein, 181)

The teacher to the pupil: «Steh auf, wenn ich mit dir rede. Und sieh mich an.» (Hein, 2005)

\section{Demand:}

The grandfather to the daughter-in-law and to the grandson: «Bringt mich wieder in mein Bett!» (Noll, 113)

Father to son: Harald stellte wütend den Ton ab, der Alte protestierte. "Mach sofort wieder an! Ilse liest mir gerade vom Lumpengesindel vor!» (Noll, 145)

The necessity to fulfill the will of the speaker increases the level of categoricalness of the utterance, this is possible not in each case of expression of imperativeness and may be face-threatening for the supposed performer of the action because he is lower in the status or position than the speaker.

Probably, the fact that a significant number of speech acts of imperative character do not presuppose obligatory execution of action by the addressee is explained by it. The speaker allows the addressee a certain freedom of choice, which is revealed in the opportunity to refuse to fulfill the action for various reasons. In such cases speech acts with imperatives can be differentiated depending on the fact in whose interests the action will be fulfilled.

The addressee can fulfill the will of the speaker for the benefit of the speaker (request, entreaty, appeal, threat), in his own interests (advice, instruction, warning, permission, encouragement, consolation) or both in his own interests and in interests of the speaker (invitation, offer).

The listed speech acts can be followed by naming the reasons or motives of the required action from the point of view of the speaker. Thereby the speaker provokes and pushes the listener to fulfill the action which he is interested in.

Request: «Bitte, mach die Tür fest zu, damit die Wellensittliche nicht fortfliegen.» (Noll, 33)

Entreaty: «Bitte helfen Sie mir!» ... «Mein Gott, endlich! Bitte helfen Sie mir». (Kehlmann, 2009)

Threat: "Verschwinde, du kleiner Bastard, eh mir die Hand ausrutscht. - Nein, solch ein Bengel. Den müsste man mal übers Knie legen.» (Hein, 167)

Warning: "Das ist keine gute Idee. Ich meine, wenn wir hier stehen und zuschauen, kann uns keiner an den Wagen fahren. Aber wenn wir zu denen gehen, das ist ganz etwas anderes. Wenn das einer von der Schule erfährt, und genau das wird passieren, dann mach dich auf was gefasst.» (Hein, 180)

By means of the imperative the speaker can also induce the addressee to fulfill the action for the benefit of the addressee. In this case he demonstrates his interest in the fate of the listener, acting as an adviser, an authoritative expert, a mentor or an assistant.

By this the speaker demonstrates the addressee that he knows (or thinks that knows) the best solution to the problem in the situation.

Advice: «Jetzt bleib mal zwei Tage im Bett, dann bist du wieder fit.» (Noll, 323)

Der Polizist warf einen Blick zu seinem Kollegen, der abfällig mit der Hand winkte. «Also, verschwindet. Und ich gebe euch den guten Rat, lasst euch heute nicht mehr auf der Straße blicken. Wenn ich euch noch einmal aufgreife, nehme ich euch mit. Ist das klar?» (Hein, 174)

Permission: «Nimm dir, was dir gefällt», sagte ich, »du wirst ja ein paar kleine Vorlieben haben, oder?» (Hein, 285)

Instruction: «Darum musst $d u$ dich vorher kümmern. Wenn du die Adresse bekommst, dann besorge dir einen Stadtplan oder irgendetwas Ähnliches. Und präg dir alles ein. Nie jemanden fragen, auch nicht in Berlin. Mit keinem sprechen, nicht auffallen, keiner soll sich an dich erinnern.» (Hein, 246)

Consolation: «Machen Sie sich keine Sorgen», sagte Jenny, «den kriegen wir schon wieder hin!» (Noll, 69)

Encouragement: «Opa, reg dich nicht so auf, alles wird gut ...» (Noll, 327)

The imperative often forms speech acts, where not only the listener is expected to participate in the action, but the speaker as well. The speech acts of invitation and offer could be given as examples. They have much in common and are hard to distinguish in speech:

Invitation: ... dass Bernhard eines Tages ... nach dem Unterricht zu mir sagte: «Komm, gehen wir zum Fluss. Oder musst du gleich nach Hause?» (Hein, 85)

Offer: «Machen wir für heute Schluss. Mir ist der Spaß vergangen.» (Hein, 346)

The invitation can be treated as a request to take part in something, to be engaged in something. The offer should be considered as granting the addressee an opportunity to choose for execution of any action in the future. However, the offer unlike the invitation does not necessarily assume partnership of the speaker and can be aimed only at the listener. Besides, the invitation to greater extent obliges to action, than the offer.

Quite often the imperative is used in the contactive ( 8 cases of the use) and metacommunicative (20) speech acts. We have attributed greeting, farewell, presentation / acquaintance, giving greetings/regards to somebody and also wishes in congratulations to contactive speech acts with the imperative which are regarded as speech clichés:

«Grüß Rieke von mir.» (Hein, 287)

Metacommunicative speech acts are presented mainly by the imperative structures designed to draw attention or to keep interest towards the main speech act of the utterance:

«Stell dir vor, er will wieder heiraten!» (Noll, 126)

«Sag mal, du hast doch Abitur und könntest studieren, willst du allen Ernstes Altenpfleger werden?» (Noll, 168)

«Denk dir», sagte sie und lachte herzlich, «ich war mit Harald übers Wochenende in Baden-Baden...» (Noll, 259) 
«Vergiss nicht, ich habe es schon erlebt. Ich weiß, wie es ist, ein Brand.» (Hein, 336)

The function of contactive and metacommunicative utterances is the phatic one. It serves communication, helps to establish, maintain and terminate the speech contact. Imperative semantics here has a blurred character. In this regard P. Auer believes that the use of the imperative for maintenance of interest to the main utterance (i.e. in metacommunicative speech acts) is a result of process of grammaticalization of the imperative, when on the basis of the imperative mood a discursive, or text forming marker develops [28].

More rarely the imperative is used in non-imperative speech acts, for example, in speech acts of modal and evaluative character (persuasion and wish), where the opinion on the forthcoming action or event is expressed and their evaluation is given [29].

The wish implies positive evaluation of the desirable. It can be individualized or have a form of a speech cliché or a ritual (a wish of good luck, a good trip, etc.). In the latter case the wish can also be referred to contactive speech acts:

«Schlaf gut, Opa», sagte Max und löschte das Licht. (Noll, 2010)

In the speech act of persuasion the speaker by means of words tries to make the listener believe him. Usually this speech act is complex in its structure. The imperative plays here a role of one of the components adding the convincing effect. In this regard the imperative can repeatedly be used within this speech act:

Plötzlich legte sich eine Hand auf meine Schultern, ich fuhr herum, neben mir stand Herr Frieder, ein Arbeitskollege von Vater (...). «Komm, Jungchen, wir gehen jetzt», sagte er. Ich schüttelte den Kopf und wand mich aus seinem Griff. « $\underline{\text { Komm }} »$, sagte er nochmals, «jetzt ist der Spaß vorbei. Ab jetzt wird es ungemütlich.» Er sagte es so leise und eindringlich, dass ich unsicher wurde und mich nach Bernhard umsah. «Man muss immer wissen, wann Schluss ist. Komm.» (Hein, 182)

Even less often the imperative forms speech acts of the informing character (in our empirical material these are consent and refusal). In these speech acts the imperative most often acts as an additional element, focusing the listener on the main part of the futureoriented speech act [29].

Consent: «Na geh schon», sagte ich schließlich, «ich pass hier auf.» (Hein, 2005)

Or it is "tied" to concrete lexical filling of the utterance.

Refusal: Ich wollte ihn zum Abschied küssen, er drückte mich zurück. «Lass das sein. Nicht hier auf der Straße, Kathi.» (Hein, 2005)

In formation of the majority of the listed speech acts the imperative competes with some other linguistic means. As the actions being the basis of the imperative utterances refer to the future, the linguistic units with future semantics capable of expressing motivation can act as competitors of the imperative.

An opportunity to replace the imperative with other linguistic means does not deny the fact that the imperative is a neutral form of imperativeness and that it takes the leading role in expression of imperative semantics in the direct speech of characters in the fictional discourse [30]. According to the empirical data and the result of analysis the imperative is the most frequently used linguistic means in speech acts of request, advice, demand, consolation, order, entreaty, invitation, wish, appeal, command, as well as in the contactive and metacommunicative speech acts. It is also commonly used in speech acts of permission, offer, threat and instruction.

\section{Conclusion}

The specifics of semantics and pragmatics of the imperative, mainly its orientation to the situation of immediate communication with the purpose to change the reality (performance or prevention of any action from the addressee of will), make the imperative one of the most significant verbal forms of expressing incentive to the action in the direct speech of characters in the German fictional discourse.

Categorial characteristics of the imperative indicate its morphological properties (one of the verb moods), and syntactic properties (it is used in a special communicative type of sentence, - incentive sentence). In this regard the imperative paradigm becomes also variable. In a narrow sense the imperative includes only forms of the $2^{\text {nd }}$ person singular and plural. In a broad sense the forms of the imperative of a polite distance (with $\mathrm{Sie}$ ) and forms of exhortative sense (with wir) also belong to the imperative paradigm. In respect of semantics the imperative is one of the neutral means of imperative semantics expression.

Along with an imperative the imperative meaning can be expressed by some other linguistic means (f.e. by Präsens, Futur I, modal verbs, infinitive forms, forms of participle perfect), which also actualize the semantics of future time. This demonstrates the existence of the explicit competition in the semantic zone of imperativeness, on the one hand, and the bond of imperativeness and futurality on the other hand.

The analysis of the direct speech of characters in the fictional discourse showed that the imperative differs from the competitors not only in relative neutrality of expression of the imperative meaning, but also in its high frequency: approximately $40 \%$ of cases of expression of imperativeness. The imperative is involved and represented practically in all speech acts of imperative character. The form of the imperative is frequent also in speech acts of contactive and metacommunicative character with blurred imperativeness. The width of semantic range and pragmatical multifunctionality of the imperative also allow using it in non-imperative speech acts of the modal and evaluative character.

\section{References}

1. V.S. Hrakovsky, A.P. Volodin Semantics and typology of the imperative. Russian imperative. (Nauka, Leningrad, 1986)

2. V.A. Plungyan Introduction to grammatical semantics: grammatical meanings and grammatical 
systems of languages of the world: tutorial. (RGGU, Moscow, 2011)

3. B.V. Yakushin Hypotheses of origin of the language. (Nauka, Moscow, 1984)

4. V. Yu. Gusev The typology of imperative. (Languages of Slavic culture, Moscow, 2013)

5. A. V. Zelenshchikov Proposition and modality. (St.Petersburg State University, SPb., 1997)

6. P.H. Matthews The Concise Dictionary of Linguistics. (University Press, Oxford, 2014)

7. V. A. Zerebkov Das Verb. Ein Hilfsbuch zur deutschen Grammatik. (Hochschule, Moscow, 1977)

8. R. Thieroff Das finite Verb im Deutschen: Tempus Modus - Distanz. (Narr, Tübingen, 1992)

9. O. I. Moskalskaja Grammatik der deutschen Gegenwartssprache. (Academia, Moscow, 2004)

10. E. Leiss Die Verbalkategorien des Deutschen: ein Beitrag zur Theorie der sprachlichen Kategorisierung. (De Gruyter, Berlin, New York, 1992)

11. Grammatik der deutschen Sprache. Bd. 3. (De Gruyter Berlin, New York, 1997)

12. J.Zinken, A. Deppermann Imperative Turns at Talk, The design of directives in action, $A$ cline of visible commitment in the situated design of imperative turns action. 27-63. (John Benjamins Publishing Company, Amsterdam, Philadelphia, 2017)

13. W. Abraham Modalität: Epistemik und Evidentialität bei Modalverb, Adverb, Modalpartikel und Modus, Die Urmasse von Modalität und ihre Ausgliederung. Modalität anhand von Modalverben, Modalpartikeln und Modus. 251-302. (Tübingen, 2009)

14. M.-L.Sorjonen, L.Raevaara, E.Couper-Kuhlen Imperative Turns at Talk. The design of directives in action, Imperative turns at talk. An introduction action, 1-24. (John Benjamins Publishing Company, Amsterdam, Philadelphia, 2017)

15. F.Simmler Festschrift für Herbert Kolb zu seinem 65. Geburtstag, Zur Geschichte der Imperativsätze und ihrer Ersatzformen im Deutschen 642-691. (Bern, 1989)

16. V.N. Nemchenko Grammatical terminology. Dictionary. (Flinta, Nauka, Moscow, 2011)

17. Yu. P. Knyazev Grammatical semantics. Russian in typological perspective. (Languages of Slavic cultures, Moscow, 2007)

18. L. S. Yermolaeva The system of moods in modern German (compared to other German languages). (Mosc. state. ped. in-t of foreign languages of $\mathrm{M}$. Thorez, Moscow, 1976)
19. K.-E.Sommerfeld, G.Starke Grammatischsemantische Felder der deutschen Sprache der Gegenwart. (Verlag Enzyklopädie, Leipzig, 1984)

20. A. V. Bondarko Theory of functional grammar. Temporality. Modality, Reality / irreality and potentiality. 72-79. (Nauka, Leningrad, 1990)

21. K. Byuler Theory of language. Representative function of language. (Progress, Moscow, 2001)

22. A.Y. Aikhenvald Commands. A Cross-linguistic Typology, Imperatives and commands: a crosslinguistic view. 1-45. (University Press, Oxford, 2017)

23. A. V. Bondarko Theory of functional grammar. Temporality. Modality, To the analysis of categorial situations in the sphere of modality: imperative situations. 80-89. (Nauka, Leningrad, 1990)

24. G. G. Silnitsky Theory of functional grammar. Temporality. Modality, Functional and communicative types of moods and their temporal characteristics. 90-110. (Nauka, Leningrad, 1990)

25. G.F. Muzykantov The Text in speech activity, Contrast-like semas generating expressivity of morphological synonyms of the imperative. 87-93. (IYaZ, Moscow, 1988)

26. S.Heinold Deutsche Sprache, Gut durchlesen! Der deutsche Imperativ und seine funktionalen Synonyme. 1, 32-56. (2012)

27. V. S. Hrakovsky . Theory of functional grammar. Temporality. Modality, Imperativity. 185-238. (Nauka, Leningrad, 1990)

28. P. Auer, Imperative Turns at Talk. The design of directives in action, Imperatives - The language of immediate action. 411-423. (John Benjamins Publishing Company, Amsterdam, Philadelphia, 2017)

29. E.V.Bodnaruk The St.Petersburg State University Bulletin. Series. Classification of speech acts with future semantics (on German material). 9. 2. 62-75. (2015)

30. E.V. Bodnaruk Category of futurity in modern German: semantic-pragmatic and functionaldiscursive aspects of research: Dissertation. (Arkhangelsk, 2016)

\section{List of sources}

1. Ch.Hein Landnahme. (Suhrkamp, Frankfurt am Main, 2005)

2. D.Kehlmann Ruhm. (Rowohlt, Hamburg, 2009)

3. I. Noll Ehrenwort. (Diogenes, Zürich, 2010) 